\title{
Details of the Contributors, with Summaries of their Essays
}

Avriel Bar-Levav is Senior Lecturer in Judaic Studies in the Department of History, Philosophy and Judaic Studies at the Open University of Israel, and editor of Pe'amim: Studies in Oriental Jewry, published by the Ben-Zvi Institute, Jerusalem, Israel.

Bar-Levav offers a framework for depicting and understanding the varied Jewish attitudes towards death, particularly in the medieval period. The author differentiates between death as an idea and death as a reality, and between the presence and absence of death. He suggests that, by and large, death is marginal in the framework of Jewish culture. Jewish attitudes towards death can be anchored between time, space and texts. There is a time of mourning and remembrance, there is a place for the dead (the cemetery), and there are distinct texts that are used in the contexts of dying and mourning. The paper describes various axes along which ideas about death may be perceived: death as punishment or desideratum; the amalgamation of the personality during life and its disintegration in death; the relationship between this world and the world to come; the connection of the soul and the body; and the burial society as a social and religious organization. Death offers a moral perspective on life, and this is also connected with the comprehension of dying as a life passage, and with the construction of the idea of the proper death.

Frederick S. Paxton is the Brigida Pacchiani Ardenghi Professor of History at Connecticut College, in New London, Connecticut, U.S.A.

Paxton's paper attempts to gather together the myriad social and religious behaviours around death, dying and commemoration of the dead in the Latin Christian Middle Ages within a common conceptual framework: the medieval economy of salvation. He argues that the medieval economy of salvation grew out of the patristic notion of the divine economy, whereby God's gift of his son's life opened up a path to eternal salvation for humankind, to eventually encompass the transfer of people, goods, lands and incomes from private hands to religious communities in exchange for masses, psalms, prayers and alms for the poor, which were then offered to God in return for the salvation of the souls of the donors and their families. Paxton's particular focus is on the early growth of the economy of salvation, which culminated in the extraordinary success of the Benedictine Abbey of Cluny in the eleventh century and twelfth centuries. 
Stefan C. Reif is Emeritus Professor of Medieval Hebrew Studies and Fellow of St John's College at the University of Cambridge, U.K.

Reif began his response to Paxton's keynote address by stressing the need for Jewish scholars clinically to investigate the reasons, both theological and more general, for the revolutionary developments in death liturgy, especially among the Ashkenazi communities of the high Middle Ages. He stressed the major contribution made by pre-medieval and medieval Jewish teachers to liturgical development, how closely related Jewish trends were to their Christian counterparts, and the link made in the rabbinic sources, especially in liturgical custom, between prayers for the dead and charitable gifts. Reif also pointed to the tensions between halakhists and philosophers on one side of the religious spectrum and mystics on the other with regard to customs appertaining to burial and cemeteries. His concluding remarks drew parallels between Christian and Jewish periods of mourning, trends towards standardization and the composition of special benedictions for those who performed special communal tasks.

Shmuel Shepkaru is Associate Professor of Judaic History at the University of Oklahoma, U.S.A.

This article points out that the three Hebrew accounts pertaining to the massacres of the Ashkenazi Jews during the First Crusade do not mention resurrection when discussing the afterlife of the Jewish victims. Given the centrality of the doctrine of resurrection in rabbinic Judaism and the high probability that the authors of these Ashkenazi accounts were rabbis themselves, the absence of resurrection in these accounts is intriguing. As the references to talmudic, midrashic, and biblical texts (Daniel 12) that do mention resurrection suggest, the Ashkenazi accounts intentionally avoided resurrection. This article proposes several reasons for this absence. By ascribing to the victims an immediate reward in heaven, the accounts vindicated God and the victims, thus addressing the question of theodicy. Other factors were the role resurrection played in the attempts to impose forced conversion on the Jews, and in the Christian propaganda of the First Crusade in general.

Andreas Lehnardt is Professor of Jewish Studies at the Faculty of Protestant Theology, Johannes Gutenberg-University, Mainz, Germany.

This article deals with the late custom of reciting an additional qaddish to commemorate the anniversary of a parent's death. As often noted, Ya'aqov ben Moshe Moellin ('Maharil') was apparently the first to mention the custom. The term yahrzeit already occurs in the responsa of the Austrian, Rabbi Shalom of Wiener Neustadt, a teacher of the Maharil. Significantly, at the very time when yahrzeit customs were being adopted by Ashkenazi Jews in the thirteenth- 
fourteenth centuries, comparable developments were occurring in Catholic Christianity. The paper therefore goes on to deal with Christian sources that provide insights into the development of similar liturgical usages relating to the Paternoster or Lord's Prayer in the fourteenth century. While there may not exist a direct and demonstrable Christian influence on the Jewish liturgical practice, the evolution of a similar custom in the same region and under similar circumstances may indicate how a dominant Christian environment could have left its imprint on a smaller religious group operating within it.

Ruth Langer is Professor of Jewish Studies in the Theology Department at Boston College and Associate Director of its Center for Christian-Jewish Learning, U.S.A.

Although the prayer's origins remain unknown, European Jews, by the time of the Rishonim, expected that recitation of the liturgical composition known as Șidduq ha-Din would be a central element of burial rituals. Its conclusion with biblical verses provided the liturgical context for the recitation of qaddish at the burial itself. After discussing the evidence for the prayer in early and high medieval rabbinic literature, this paper presents critical studies of the manuscript evidence for the prayer's specific forms in the various high medieval rites of Ashkenaz, France, and Spain. This data in turn allows identification of the core literary and ideational features of the text and an understanding of how various communities elaborated upon it and transformed its meaning. The prayer moves from simply accepting God's justice in the face of death, to meditating on divine justice and mercy more broadly, and to petitioning for divine mercy for the living community.

Peter Sh. Lehnardt is Senior Lecturer in Medieval Hebrew Literature in the Department of Hebrew Literature at Ben-Gurion University of the Negev, Beersheba, Israel.

This paper intends to illuminate the use in Ashkenaz of the poetic Sidduq Ha-Din, namely, Ha-Sur Tamim Be-Khol Po'al, in the context of its forming a part of the composite burial ceremony in the rite of Rome. To that end, it includes an annotated, critical edition of the textual part of the burial ceremony that goes back to Apulia in the eighth and ninth centuries and that was used and transmitted in Italy throughout the Middle Ages and up to the seventeenth century under the heading of Sidduq Ha-Din. The different textual elements of this agenda mortuorum are then considered and evaluated according to the relevant literary history of liturgical poetry and as parts of the burial ceremony as a rite de passage for the dead and mutatis mutandis for the mourning community. 
Joseph Isaac Lifshitz is Senior Fellow at the Shalem Center, Jerusalem, and a Fellow at the Goldstein-Goren Diaspora Research Center, Tel Aviv University, Israel.

The prayer, Av ha-rahamim ('Father of Mercy'), recited to this day in Ashkenazi communities during the Sabbath morning prayers, is mentioned in the Worms community records as a prayer that was composed in memory of those killed in the riots that took place during the First Crusade. This paper demonstrates how Av ha-rahamim, which may initially have been composed as a memorial prayer, had much deeper theological meanings ascribed to it in later periods. It was these theological meanings that gave Av ha-rahamim the importance that it has carried into our own day. The first was the idea of revenge as a proof of the existence of a just God. The second perceived the martyrs as holy figures - not mere mortals who required mercy - and their memory became a source of strength for the Jews, not only when facing their Christian neighbours, but primarily when facing the Creator Himself.

Abraham Gross is Professor in the Department of Jewish History at Ben-Gurion University of the Negev, Beersheba, Israel.

The massacres of the Jewish communities in Germany at the hands of the Crusaders, and the collective suicides arising out of that persecution, during the spring of 1096, have been recorded in Jewish and Christian sources, mainly in the form of chronicles. This article deals with another type of literature composed in the wake of those tragic events, namely, Jewish liturgical verse [piyyut]. The author highlights aspects of memory and memorialization embedded in that essentially religious poetry. It is claimed that the significant corpus of 1096 liturgy, which describes graphically the bloody events, and hints at specific facts and individual martyrs, reflects the social and emotional needs of the first and second generation of survivors for memorialization of the events and of the victims. Those needs, it is claimed, are not so different from those with which we are familiar in our own day, although the medieval medium of expression discussed here is characteristically a more religious one.

Yechiel Y. Schur teaches at the University of Pennsylvania and is Klatt Family Director for Public Programs at its Herbert D. Katz Center for Advanced Judaic Studies, Philadelphia, U.S.A.

While Jews in medieval Ashkenaz clearly believed in the bodily resurrection of the dead in the days to come, certain Jews - like their Christian counterparts - also believed in revenants, that is, in dead bodies coming alive in the immediate period after death. Moreover, like Christians, some Ashkenazi Jews, including leading rabbis, believed that revenants are composed of actual corporeal elements of the deceased and are not merely spiritual entities (like 
ghosts), lacking tangible, corporeal elements. Following a brief survey of the topic in rabbinic texts, this paper considers references to revenants in exegetic texts, halakhic works, and paradigmatic stories, primarily from the thirteenth and fourteenth centuries. The overall aim of the paper is to demonstrate the novelty of these Ashkenazi views and the degree to which Jews and Christians held common views on revenants.

Nati Barak lectures in the Overseas Students Program at Tel Aviv University, Israel. He spent a year at the Hochschule fur Jüdische Studien in Heidelberg, and is currently a high school principal.

The article discusses the burial of the deceased together with items of spiritual value and covers the two centuries following the Black Death. Attention is centred on the changes in ritual and in the perception of death in the Ashkenazi communities of Germany and northern France, as reported in halakhic and historical sources deriving from Austria. While in generations preceding the Black Death requests for the burial of items of special value were fulfilled at the time of interment, a subsequent custom was also to permit this at a later date by opening the grave and placing the item inside it, while adhering to explicit rabbinical instructions. Through such an act, the surviving family could remain in a form of physical contact with the deceased, as well as striving for a spiritual connection with them by praying or giving charity for their souls. The sealing of the grave was not then necessarily final.

Avraham (Rami) Reiner lectures in the Department of Jewish Thought at BenGurion University of the Negev, Beersheba, Israel.

This article begins by describing the major discovery of some 1,500 Jewish tombstones from 1147-1346 in Würzburg, Germany, in 1988. In spite of the size of this collection and the existence of lists of those killed in the Second Crusade (1147) and in the pogroms of 1298, there are difficulties about drawing conclusions, especially demographic, from this collection. Three women's tombstones are then considered. Two are of daughters of noted rabbinic families, one of whom, the grand-daughter of Rabbi Eli'ezer ben Nathan ('Raban') of Mainz, died during childbirth. Most surprising is that of a convert who died in the mid-thirteenth century, and whose tombstone's wording reflects the cultural world of her earlier faith. The article concludes with details of tombstones of Jews who died at the hands of Christians 'in sanctifying the Name' (of God). Although other tombstones have the usual blessings or wishes for the deceased as they enter into their eternal rest, these do not. The author offers a possible explanation for this phenomenon.

Nathanja Hüttenmeister M.A. is a research assistant at the Salomon Ludwig Steinheim-Institute for German-Jewish History at the University of DuisburgEssen, Germany. 
The Jewish cemetery of Mainz is one of the oldest Jewish cemeteries of medieval Ashkenaz. When the Jews were expelled from Mainz in 1438, the gravestones were spoilt and used for building purposes. In 1449, the premises were partly returned to the Jewish community that had returned to Mainz, and they served that community until 1880. Over 200 medieval Jewish gravestones have been found in Mainz in the last two hundred years, dating from the years 1049 to 1421 , among them a stone from the year 1049, which is the oldest Jewish gravestone ever found in Germany. Most of the gravestones have been returned to their places of origin and assembled in a field adjacent to the Jewish cemetery, constituting a 'memorial cemetery'. In 2008, additional gravestones from the end of the eleventh to the middle of the thirteenth century were discovered, together with some fragments. These stones are discussed in this paper.

David Malkiel is Professor in the Israel and Golda Koschitzky Department of Jewish History at Bar-Ilan University, Ramat Gan, Israel, and has recently completed a study of the tombstones of Paduan Jewry, 1529-1862.

Hebrew epitaph poetry becomes the norm in sixteenth-century Italy and remains popular for nearly three centuries. This study focuses on its appearance in Padua in the mid-cinquecento, as the reception of the epitaph poem reflects the acculturation to the Italian environment of the largely Ashkenazi constituency. The sixteenth and seventeenth centuries are the heyday of the epitaph poem in Padua, in quantity and quality, and this article surveys the form and content of this body of literature in the various phases of its development. This period is followed by one of stagnation and enervation in the eighteenth century, when the epitaph poem is ubiquitous but no longer creative. The epitaph is radically redesigned in the early nineteenth century, from approximately 1820. Prose inscriptions replace the poems, and these are more personalized, underlining the new importance of the individual in the modern era.

Mauro Gabriele Perani is Professor of Hebrew at the University of Bologna, Italy, and a former President of the European Association for Jewish Studies.

Perani introduces the Corpus Epitaphiorum Hebraicorum Italiae (CEHI), a project founded by him to publish a complete corpus of the epitaphs preserved in Italian Jewish cemeteries of the sixteenth-nineteenth centuries. In the Barocco period and later, the art of writing Hebrew epitaphs, true or fictitious, commissioned by relatives or written for himself as a personal after-deathmemory, became a discrete literary genre, formulated in rhyme and rhythm by rabbis and learned scholars. This poetical feature is typically Italian, and the epitaphs often constitute a true diwan of poetry, as well as an important source for historical and genealogical study. Perani also illustrates the evolution, lan- 
guage and style of Italian Jewish epitaphs as well as their palaeographical development and stylistic characteristics. This source, testifying to the concept of the death in the Italian Jewish communities, may be integrated with other manuscript evidence such as personal records or the statutes of charitable fraternities charged with burying the dead.

Minna Rozen is Professor in the Department of Jewish History at the University of Haifa, Israel, and specializes in the history of the early modern and modern Mediterranean.

Rozen pursues several avenues of research arising from the systematic study of large cemeteries, and combines her findings with knowledge derived from other sources. The material used here was assembled and processed from four cemeteries in Istanbul where Jews were buried during the Ottoman era: Hasköy, Ortaköy, Kuzguncuk, and the Italian cemetery in Şişli, all in all some 40,000 tombstones. The case selected to demonstrate the research potential concerns a specific group from the Jewish community of Istanbul, with the surname of 'Romano', and one of its branches in particular, whose members were buried in the Hasköy cemetery and were known by the name 'Roman.' The research reveals how this family, which apparently originated in the city of Rome, weaved family connections with Romaniot and Sefardi Jews of its own class. The varied material also exemplifies the intellectual and cultural connections of family members with seventeenth-century Muslim and Christian cultures. 
